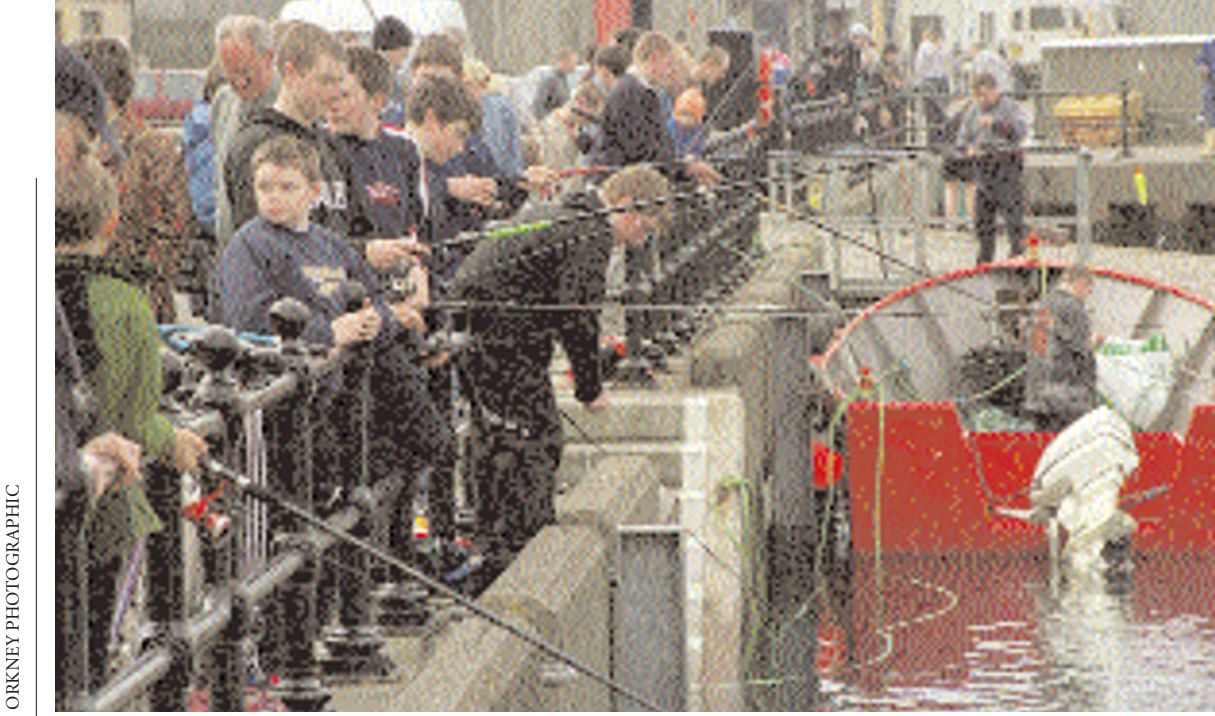

Food for thought: publicity over the Orkney fish breakout has raised the profile of ecological concerns.

\title{
Stream of escaped farm fish raises fears for wild salmon
}

Natasha McDowell, London

The escape of an estimated 100,000 farmed salmon in the Orkney Islands, off the north coast of Scotland, has highlighted mounting concerns about the ecological impact of such incidents on natural salmon stocks.

A Scottish parliamentary committee is currently investigating the impact of fish farming. But the Scottish Executive, which has been responsible for fishing and the environment since its establishment in 1999, has been accused of ignoring the issue.

To judge from scenes in Orkney last week, when hundreds of locals appeared to relive the movie Whisky Galore as they scrambled to harvest the salmon, many of the escaped fish will end up safely ensconced in home freezers.

But according to data collected in Norway and elsewhere, farmed fish from less celebrated escapes are contaminating and sometimes overwhelming the gene pools of natural fish. The offspring of farmed fish, some data suggest, are often unable to complete the heroic salmon runs by which the natural species navigate between spawning grounds inland and breeding grounds in the ocean. Critics say that, together with the rampant transmission oflice and disease from fish farms to natural stocks, the result is threatening the very survival of natural salmon runs in countries such as Scotland, Canada and Norway.

Kenny Black, a marine biologist at the Dunstaffnage Marine Laboratory in Oban, has been asked by the Scottish parliament to prepare a technical report for its inquiry. "The increasing level of escapes means we risk the extinction of the genetic integrity of native salmon populations," he says. "Farmed fish are fairly homogenous and so there will be an irreplaceable loss of genetic diversity." However, as Black notes, "fish farming is here to stay. What we need to do is identify the areas of most concern and do something about them."

Black's report, when it is delivered to the parliament's committee on transport and the environment next month, will indicate where more research is needed to understand better the impact of escaped farm fish.

Although containment techniques for farm fish have improved, the number of escapees has not fallen because the industry is expanding, says Black. According to environmental groups, about a million salmon have escaped from farms in Scotland since 1998.

"So far, the government has done nothing," says Robin Harper, a Green member of the parliament.

An initial report from the committee, released last month, called for tagging to allow escaped fish to be traced, and the introduction of associated penalties for fish farmers. It also recommends that farm fish be sterilized.

Ian Fleming, a marine biologist at Oregon State University, who has studied the impact of salmon farming in Norway, says that official counts of escaped farm fish there are "conservative estimates". As a result of the escapes, he says, differences between wild and farmed populations are halving every 10 generations. In some rivers $80 \%$ of salmon are of farmed origin.

Fleming has found that, where farmed fish have mixed with natural ones, 30\% less offspring make it from breeding grounds to the ocean. He says that the negative effects of hybridization do not usually become apparent until the second generation, when the coadapted genes that tell the fish when to breed and how to find food become separated.

Research on the mortality rates of secondgeneration fish is being undertaken by Andrew Ferguson of Queen's University Belfast, and will be published shortly. The results could lead to new rules for fish farming. "We need a balanced approach soundlybased on scientific evidence," says Bristow Muldoon, a Labour member of parliament and chair of the Transport and the Environment Committee.
White House plans to increase 'relevance' of climate research

Mark Schrope

The United States is planning to restructure its climate-change research programmes in an effort to make them more relevant to government policy.

White House officials say that the reorganization will help the government to answer scientific questions that influence policy, as well as improving coordination of the entire research effort.

At the moment, climate-change research is coordinated by the US Global Change Research Program (USGCRP), which was set up in 1989 by former President George Bush.

But officials in the current administration say that the USGCRP which is overseen by one of seven government committees that deal with technical issues - is too far removed from cabinet-level decisions. They also say that its scope excludes large chunks of climate-change research, including, for example, about half of the related activities at the National Oceanic and Atmospheric Administration.

Under the proposals, a new Committee on Climate Change Science and Technology Integration, whose members will include most members of the cabinet, will be responsible for making recommendations to the president on climate-change issues. In cooperation with a working group on climate-change science and technology, the new committee will set research priorities for climate change, White House documents say.

Two new offices, a Climate Change Science Program Office and a Climate Change Technology Program Office, will coordinate the government's climatechange research.

John Marburger, director of the White House Office of Science and Technology Policy, will help to run the integration committee. He says that the new structure will increase the impact of climate-change research on policy by focusing research on the government's priorities.

But Richard Moss, director of the USGCRP coordination office, says that it will be a challenge for people carrying out long-term basic research to compete with those in areas that have potential for short-term policy application.

Marburger aims to have the system running by the end of the year, and does not envisage problems along the way. "I don't think there are too many different ways of accomplishing what's needed," he says. 